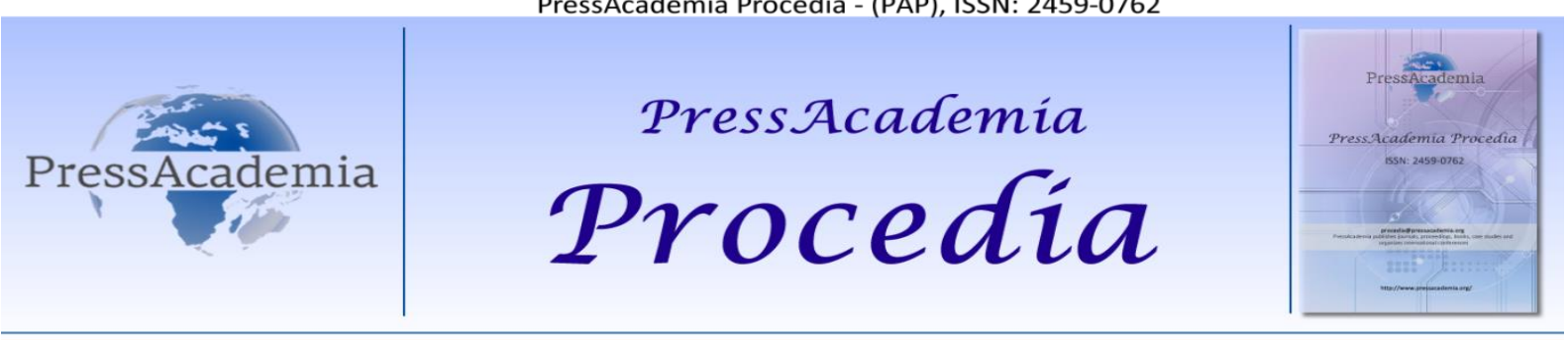

Global Business Research Congress (GBRC), May 24-25, 2017, Istanbul, Turkey.

\title{
THE EFFECT OF AUTHENTIC LEADERSHIP ON ORGANIZATIONAL LEARNING PROVIDING ORGANIZATION THE ABILITY TO ADAPT QUICKLY AND CONVENIENTLY TO CHANGING CIRCUMSTANCES
}

\author{
DOI: 10.17261/Pressacademia.2017.432 \\ PAP-GBRC-V.3-2017(47)-p.457-471
}

\author{
Hanife Sallitepe ${ }^{1}$, A. Begum Otken ${ }^{2}$, Hayriye Senem Gol Beser ${ }^{3}$ \\ ${ }^{1}$ Yeditepe University, Istanbul, Turkey. hanifesallitepe@yahoo.com \\ ${ }^{2}$ Yeditepe University, Istanbul, Turkey. begum.otken@yeditepe.edu.tr \\ ${ }^{3}$ Yeditepe University, Istanbul, Turkey. senemgol@yeditepe.edu.tr
}

To cite this document

Sallitepe, H., A. B. Otken and H.S.G. Beser, (2017). The effect of authentic leadership on organizational learning providing organization the ability to adapt quickly and conveniently to changing circumstances. PressAcademia Procedia (PAP), V.3, p.457-471.

Permemant link to this document: http://doi.org/10.17261/Pressacademia.2017.432

Copyright: Published by PressAcademia and limited licenced re-use rights only.

\begin{abstract}
Since the beginning of the 21st century business world and society in general is changing rapidly as never before. The uncertainty of the new competitive environment is dynamic, short-term, uncertain and replacing the natural foundations of the competition. Organizations have to cope with all pressures and have to find their success path through the increasingly complex environment. Organizational learning is one of the crucial processes that facilitate to adapt quickly and conveniently to changing circumstances and enhance survival chance of the organization. Leaders are expected to encourage organizational learning to attain competitive advantage. Organizational learning and transformation affected by positive behaviors of a leader and leads to affirmative upward spirals on them. Previous research represent that organizational learning is associated with different kinds of leadership styles. However, in literature there is not any encountered relationship between Organizational Learning and Authentic Leadership style. The aim of this study is to provide an understanding of the relationship between Organizational Learning and Authentic Leadership style. This research bears the distinction of being the first study that argues the relationship between Authentic Leadership and Organizational Learning; therefore it is an important contribution to the relevant literature in this area. Study was conducted in private sector organizations that operate in banking and insurance sector. The sample of the study is consisted of 200 white collar employees. The results indicated that Authentic Leadership significantly has influence on Organizational Learning.
\end{abstract}

Keywords: Authentic leadership, organizational learning JEL Codes: D83, M10, M12

\section{INTRODUCTION}

Since the beginning of the 21st century, business world and society in general is changing rapidly as never before. There are many factors that influence change such as information revolution, globalization, increasingly rapid spread of new technologies and significance of transformation from products to services and from quantity to quality. The uncertainty of the new competitive environment is dynamic, short-term, uncertain and replacing the natural foundations of the competition. This challenging competition leads to a complicated and uncertain business environment that results sudden market transformations. Many successful companies were unable to keep up these rapid changes, or vice versa. There are such situations where buyers and suppliers can be either allies or competitors. This is a 'learn or die' war for organizations. Organizations have to cope with all of these pressures and have to find their success path through the increasingly complex environment (Burnes, 2009; Bontis, Crossan, \& Hulland, 2002; Jones, 2010; Lakhani, 2005). 
If organizations want to remain competitive they have to realize the need to acquire and make use of rising amounts of knowledge. The learning capacity of a company can be the only advantageous edge for competition in this ever-changing business environment. There are many academic articles that underline the importance of collective learning for organizations to attain sustainability for competitive edge. Organizational learning is one of the crucial processes that facilitate to adapt quickly and conveniently to changing circumstances and enhance survival chance of the organization. Additionally, organizational learning development promotes efficiency, accuracy, or profits. Many researchers agree that organizational learning is vital for organization's success. Strategically astute companies in the United States spend up to $65 \%$ of their budgets on organizational learning. This awareness pushed the organizational learning topic from academic papers through a trendy topic in business environment. As a result, there has been raising interest in organizational learning in the workplace (Burnes, 2009; Bontis, Crossan, \& Hulland, 2002; Jones, 2010; Lakhani, 2005).

Today, organizational learning is considered among the strategic management scope and explained as a factor of competition (Noruzy, Dalfard, Azhdari, Nazari-Shirkouhi, \& Rezazadeh, 2013). Leaders are expected to encourage organizational learning to attain competitive advantage (Burnes, 2009). Attention of management investigators underlines the role of leader in organizational learning development recently (Berson, Da'as, \& Waldman, 2015). Authentic Leadership is one of the popular contemporary leadership styles that has roots concentrating on affirmative thoughts such as hope, stamina, patience, optimism, welfare and the applicability of these attitudes to the organizations (Avolio, O.Walumbwa, \& J.Weber, 2009). According to Frederickson organizational learning and transformation are affected by positive behaviors of a leader and leads to affirmative upward spirals on them (Avolio \& Gardner, 2005). There are some studies emphasizing that leadership style promotes knowledge creation and transition leads to organizational learning development (Arago'nCorrea, Garci'a-Morales, \& Cordo'n-Pozo, 2007; Zagoršek, Dimovski, \& Škerlavaj, 2009; Glessner, 2016).

There are many research about leadership theory, but a few of them is related to contemporary approaches. On the other hand, organizational learning is a trend topic in recent years. Previous research represent that organizational learning is associated with different kinds of leadership styles. However, in literature there is no study showing the relationship between organizational learning and authentic leadership style. With this in mind, the aim of this study is to provide an understanding of the relationship between organizational learning and authentic leadership style.

A better understanding of these relationships will contribute to theory and provide further insight into the influence of authentic leadership on organizational learning. Understanding whether authentic leadership influences organizational learning will also help to determine whether learning environments are important investments that contribute organization's success.

This research bears the distinction of being the first study that argues the relationship between authentic leadership and organizational learning. Therefore, it is an important contribution to the relevant literature in this area.

The findings of this study can be valuable for leaders to understand how the authentic leadership approach improves organizational learning culture and to find ways for promoting learning. Besides, this research can also be valuable for people who are studying or teaching organizational behavior and change management that cover authentic leadership style and organizational learning concepts in a compact way.

\section{LITERATURE REVIEW}

\subsection{Authentic Leadership}

Erickson (1995) addresses that authentic leadership has a background more than 90 years (Gardner, Avolio, Luthans, May, \& Walumbwa, 2005). Although there are prior studies, authentic leadership (AL) attracted attention of scholars after the Inaugural Summits in Omaha, Nebraska that were hosted by Gallup Leadership Institute (GLI) of University of NebraskaLincoln in June 2004 and 2006 respectively. More than 80 scientific papers were represented and every aspect of authentic leadership is discussed in these events and outcomes were published in reputable journals such as The Leadership Quarterly (Gardner, Cogliser, Davis, \& Dickens, 2011).

Harter (2002) explains authenticity as a person's experiences with their thoughts, passions, needs, wishes, preferences and beliefs seized by self-diagnosis process. As it is understood from this definition, an authentic person's inner thoughts and feelings are parallel with his/her behavior (Avolio \& Gardner, 2005). Authentic behavior refers acting by values and preferences sincerely not for others or rewards or punishments. Erickson (2005) emphasizes that we cannot say a leader exactly authentic or not. He expresses the leader as more or less authentic (Gardner, Avolio, Luthans, May, \& Walumbwa, 2005).

As authenticity means being honest to oneself, it refers to an individual perspective. When it comes to authentic leadership, the concept enlarges from individualism to collectivism as leadership includes relationships with all the stakeholders (Avolio 
\& Gardner, 2005). Avolio, Luthans and Walumbwa (2004) interpreted authentic leadership from the positive psychology perspective and defined the concept as "those who are deeply aware of how they think and behave and are perceived by others as being aware of their own and others' values/morale perspectives, knowledge, and strengths; aware of the context in which they operate; and who are confident, hopeful, optimistic, resilient, and of high moral character" (Avolio \& Gardner, 2005). Avolio, Walumbwa and Weber (2009) redefined the concept as a "perspective of transparent and moral behavior of a leader that stimulates to be open in knowledge sharing which is needed during decision making process while evaluating the data".

Luthans \& Avolio (2003) were inspired from positive organizational behavior while developing authentic leadership theory. Furthermore, they were affected by transformational leadership theory and ethical standpoints (Gardner, Avolio, Luthans, May, \& Walumbwa, 2005). Avolio and his colleagues see authentic leadership development as a "life's program". According to them, it is not a timely training program; on the contrary, it is an on-going lifelong process that includes self-awareness and transparency journey of both leaders and followers (Avolio \& Gardner, 2005). There are generally accepted four dimensions of AL in the literature. These are (1) self-awareness, (2) balanced processing, (3) relational transparency, and (4) ethical/moral conduct (Avolio, Walumbwa, \& Weber, 2009). Avolio and Gardner defined self-awareness with five components. These are values, identity, emotions, motives and goals of an individual (Klenke, 2007). Even there are pressures from external factors, self-aware individuals act by natural instincts. They can see their self objectively and can evaluate situations from a distance from themselves. Trying to realize what happens around them helps the attainment of self-awareness (Gardner, Avolio, Luthans, May, \& Walumbwa, 2005; Klenke, 2007). According to Avolio et al. (2009) balanced processing is described as looking from different point of views to the issues and interpreting all the related data objectively during decision making process (Avolio, Walumbwa, \& Weber, 2009). An authentic leader does not exaggerate, or ignore the reality. He/She doesn't make issues complicated, but senses complex issues easily and tries to find simple and direct solutions (May, Hodges, Chan, \& Avolio, 2003). Authentic leaders are less ego-involved, so, they can evaluate relevant data objectively to reach the right perceptions about themselves and others (Gardner, Avolio, Luthans, May, \& Walumbwa, 2005). According to Kernis (2003) relational transparency can be defined as leader having unconditional trust and self-closure in his/her relationships. In this kind of leadership style, open communication is the key factor and this leads free exchange of knowledge in the organization (Luthans F. a., 2003). Authentic leaders build close relationships with others and this leads a trustworthy environment in the organization. This positive climate also encourages followers to act in the same manner. For authentic leadership development, sharing information unconditionally is very crucial and this can only be assured by transparency (Gardner, Avolio, Luthans, May, \& Walumbwa, 2005). Authentic leaders don't hide their reasoning from stakeholders. They act transparent and always think about what is fair or at least how the issue might damage stakeholders (May, Hodges, Chan, \& Avolio, 2003). Moral issues can be defined as matters that can damage or help other people. A leader is free about his/her actions, but must be aware of the results of his/her behavior over others. Core values and principles are main determinants for authentic leaders while acting ethically. We cannot name them as "saints" that put the benefit of others always above themselves, but, in a more accurate way, we can say that they always prefer collaboration (win-win solution). Authentic leaders have the ability to be aware of their responsibility to the stakeholders. They pay attention to ethical issues and learn lessons from past experiences. Sometimes leaders act unethically as they have acceptable reasons such as saving their statue or career. Authentic leaders promote ethical behavior in the organization to shape a moral climate.

\subsection{Organizational Learning}

Today's challenging competition leads to a complicated and uncertain business environment that results sudden market transformations. Many successful companies are unable to keep up these rapid changes, or vice versa. New born firms can raise big amount of capital in a short time. The learning capacity of a company can be the only advantageous edge for competition in this ever-changing business environment. According to Wick and Leon, this is a 'learn or die' war for organizations (Bontis, Crossan, \& Hulland, 2002). Organizational learning is one of the crucial processes that facilitate adapting to changing circumstances and enhance survival chance of the organization (Jones, 2010).

The organizational learning can be defined as acquisition, interpretation, storage and implementation of new knowledge in order to advance organization's problem solving capacities. Organization can stay competitive in rapidly changing circumstances by organizational learning process. Organizational Learning development promotes efficiency, accuracy, or profits for organizations (Burnes, 2009). Scholars noticed the strategic value of organizational learning in competitive business environment and as a consequence several frameworks introduced to the literature within the time (Crossan, Lane, \& White, 1999). The Strategic Learning Assessment Map (SLAM) is one of these frameworks which was proposed by Crossan \& Hulland (1997) and approaches organizational learning as a system and made an integrative contribution to the literature (Bontis, Crossan, \& Hulland, 2002). In Strategic Learning Assessment Map (SLAM) OL has five dimensions such as three learning stocks (individual-level, group-level, and organization-level), and two learning flows (feed-forward and feed- 
back) (Crossan M. a., 1997). Learning stocks include three levels; individual, group, and organization. The individual learning can be broadly defined in general as: individual competence, capability and motivation to take charge of required tasks. Intuiting and interpreting are the key processes for individual learning according to the SLAM theory. These processes need competencies (specific or generic) and motivation to accomplish the necessary tasks (Bontis, Crossan, \& Hulland, 2002). Groups create a synergy that enhances performance. The main idea behind this is whole is much more than the sum of its parts. If the employees find ways to accomplish their tasks much more effectively, then, this promotes organizational learning (Jones, 2010). According to Clynn et al. (1994), learning can be established only with continuous interactions between people in an organization. Daft and Huber (1987) consider learning among individuals as the necessity for interacting and distribution of information. Group learning includes the participation of individual interpretations to provide a shared understanding. In brief, group learning is related with integrating process. It involves items such as, work group effectiveness, productive meeting management, resource allocation and dialogue comprehension. If an organization promotes group learning, then it can generate competitive advantage. For this reason, business performance increases in the case of group learning development (Bontis, Crossan, \& Hulland, 2002). Organization level learning includes combining individual and group learning with the non-human parties of the organization such as; procedures, structures, systems and strategy. Huber (1999) entitled this kind of learning stock as "Organizational Memory". Organization-level knowledge is an intangible asset for the organization and leads to sustainability of the business performance. If a firm can increase organizational knowledge through top level then it may have a more productive system. Structure, systems and strategy are the key components for organizational-level learning stock (Bontis, Crossan, \& Hulland, 2002). Learning flows in the SLAM include two levels; feed-forward - absorbing new learning (exploration) - and feed-back - usage of past learning (exploitation) - that means the movement of knowledge from one level to another (Vera, 2004) (Bontis, Crossan, \& Hulland, 2002). Feed-forward learning refers in what ways and conditions individual learning supports group and organization level learning such as systems, procedures, culture, etc. A recent argument for organizational learning is that; it can be an impediment if the organization does not have the ability to keep up feed-forward flow such as from individual through group or from group through organization (Bontis, Crossan, \& Hulland, 2002). Feed-back learning refers in what ways and conditions organization level learning such as systems, procedures, culture, etc. supports group and individual level learning (Bontis, Crossan, \& Hulland, 2002).

The relationship between leadership and organizational learning has been subject to many researchers in organizational behavior literature. In this part of the study, some studies in the literature have taken place that have been subject to relational linkages between different leadership styles and organizational learning. In the study of Noruzy, Dalfard, Azhdari, Nazari-Shirkouhi and Rezazadeh (2013) positive correlation has been found between transformational leadership and organizational learning in Iranian manufacturing firms that was published in International Journal of Advanced Manufacturing Technology journal. Similarly, in 2007 Aragon-Correa and his colleagues (2007) proved that transformational leadership style promotes knowledge creation and transition that leads to organizational learning development in their studies among 408 major companies from Spain operating in different sectors, such as; manufacturing, services, construction and farming. Moreover, Zagoršek, Dimovski and Škerlavaj's (2009) study showed that transformational leadership has a stronger effect on organizational learning rather than transactional leadership style. However, Çakmakyapan (2009) has found that transactional leadership style has a greater impact on organizational learning rather than transformational leadership style. In this study, the sample was employees of a congress organization that operates in service industry. Another study in the literature conducted by Lakhani (2005) found that visionary leadership is significantly related to organizational learning across three different countries; United States, Malaysia and India. The study consists of 206 employees from three different engineering organizations and the results showed that the three dimensions of visionary leadership style; (1) transactional behavior, (2) transformational behaviour and (3) transformational character have a positive association with organizational learning (Lakhani, 2005). Finally, a Northcentral University research affirmed a linkage between 8 competencies of servant leadership and organizational learning in socio-culture of a military unit in Arizona (Glessner, 2016).

These sample research so far proved that there is a relationship between leadership and organizational learning. However, there is not any encountered relationship between organizational learning and authentic leadership style in the related literature.

In light of the above studies, the following hypothesis is developed:

$\boldsymbol{H}_{1}$ : There is a relationship between authentic leadership and organizational learning.

As a summary of the theoretical framework drown above, theoretical model of the study is presented below: 
Figure 1: Theoretical Model of the Study

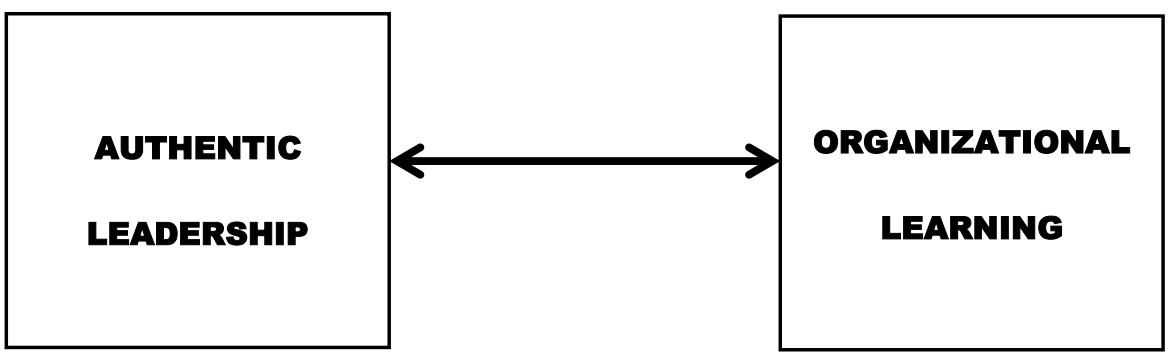

\section{DATA AND METHODOLOGY}

\subsection{Sample}

This study focuses on employees working in private sector organizations that operate in banking and insurance sector in Turkey. Specific sector limitation was chosen in order to control the impact of industry on organizations. Sample is consisted of $200(\mathrm{~N}=200)$ white collar employees working in these organizations. Participation to the study was voluntary and there is no other special criteria for attendants. Thus, convenience sampling was used for the data collection.

\subsection{Measurement Instruments}

In this study, Authentic Leadership Questionnaire (ALQ) developed by Gardner et al. (2005) was used as the survey instrument to measure the construct of Authentic Leadership. This survey instrument provided a quantitative assessment of self-awareness, balanced processing, relational transparency, and ethical/moral conduct of authentic leaders. The aggregate of the scores for these four dimensions yielded the measure of overall Authentic Leadership. A 6 point Likert scale was employed ranging from "strongly agree" (6) to "strongly disagree" (1).

The Organizational Learning Questionnaire (OLQ) survey instrument was used to measure the construct of Organizational Learning in this study. The OLQ survey instrument provided a quantitative assessment of the learning stocks and learning flows. The aggregate of the scores for learning stocks and learning flows provided the measure of overall organizational learning. Participants were asked to respond to each item on 6 point Likert scale ranging from "strongly agree" (6) to "strongly disagree" (1). (Crossan M. a., 1997)

\section{FINDINGS AND DISCUSSIONS}

\subsection{Respondents' Profile}

The sample consists of 88 females and 112 males. $81 \%$ of the sample was between the ages of $26-45$ years. $82 \%$ of the sample had a bachelor's degree, $2.5 \%$ had a high school degree and $15.5 \%$ had a postgraduate degree. The work experience of the respondents varied between 1 and 33 years. $71 \%$ of the respondents had been working for 1-9 years in their organization. The mean tenure in the current organization is 8 years. The details of descriptive statistics are demonstrated in Table 1.

Table 1: Descriptive Statistics of the Sample

\begin{tabular}{|c|c|c|c|c|c|}
\hline Variable & $\mathbf{N}$ & Percentage & Mean & $\begin{array}{l}\text { Standard } \\
\text { Deviation }\end{array}$ & Range \\
\hline \multicolumn{6}{|l|}{ Gender } \\
\hline Male & 112 & 56 & & & \\
\hline Female & 88 & 44 & & & \\
\hline Age & 200 & & 34.01 & 7.50 & $22-57$ \\
\hline \multicolumn{6}{|c|}{ Marital Status } \\
\hline Married & 106 & 53 & & & \\
\hline Single & 94 & 47 & & & \\
\hline
\end{tabular}

Education Level 


\begin{tabular}{|c|c|c|c|c|}
\hline High School & 5 & 2.5 & & \\
\hline University & 164 & 82 & & \\
\hline Post Graduate & 31 & 15.5 & & \\
\hline Tenure & 200 & 7.54 & 7.66 & $1-29$ \\
\hline Total Experience & 200 & 11.30 & 7.96 & $1-33$ \\
\hline
\end{tabular}

\subsection{Reliability of Measurement Instrument}

Reliability analysis was performed for authentic leadership and organizational learning scales and all their subscales. Authentic Leadership scale has fairly high internal consistency that has .96 overall Cronbach's Alpha value and this value is mostly above the generally agreed sufficiency level of .70. This shows that the items of each concept are interrelated. Besides, all of the subscales of Authentic Leadership have remarkable Cronbach's alpha values one by one that are very above .70. On the other hand, Organizational Learning again has a high overall value as .97 and all of its subscales are higher than .70 and this means that the second scale is also reliable. The means, standard deviations and reliability coefficients for each variable were demonstrated in Table 2.

Table 2: Means, Standard Deviations and Reliability Coefficients of Authentic Leadership and Organizational Learning Scales and Subscales

\begin{tabular}{lccc}
\hline Scale & Mean & $\begin{array}{c}\text { Standard } \\
\text { Deviation }\end{array}$ & Cronbach's Alpha \\
\hline Authentic Leadership (overall) & 4.328 & .863 & .96 \\
Self-awareness & 4.321 & .967 & .87 \\
Balanced Processing & 4.324 & .914 & .91 \\
Rational Transparency & 4.440 & .992 & .85 \\
Ethical/Moral Conduct & 4.254 & .903 & .88 \\
& & & \\
Organizational Learning (overall) & 3.921 & .629 & .97 \\
Individual-level & 3.871 & .786 & .92 \\
Group-level & 4.083 & .692 & .90 \\
Organization-level & 4.217 & .779 & .92 \\
Feed-forward & 3.760 & .707 & .89 \\
Feed-back & 3.673 & .700 & .86 \\
& & & \\
\hline
\end{tabular}

\subsection{Factor Analysis of Authentic Leadership and Organizational Learning}

Factor analysis that includes principal components solution with varimax rotation was applied to find the factor structures of authentic leadership and organizational learning scales. The items that have factor loading below .50 or loading to more than one factor was excluded from the analysis.

16 items of authentic leadership scale were entered into factor analysis. Kaiser-Meyer-Olkin (KMO) value was found as .946 and this value is mostly above the generally agreed sufficiency level of .60. This outcome demonstrated the homogeneous structure of the items and the result of Bartlett Test (.000, Chi-Square: 2629.911, df: .120) showed that the items were convenient for factor analysis. Items 7 and 13 were left out of the analysis due to cross loadings. The remaining 14 variables were loaded on two factors explaining $68.961 \%$ of the total variance.

As mentioned in the theoretical framework of this study, Authentic Leadership variable has four dimensions in the literature; these are (1) self-awareness, (2) balanced processing, (3) relational transparency, and (4) ethical/moral conduct (Avolio, Walumbwa, \& Weber, 2009). In the study of Gündoğdu (2010), authentic leadership yielded two factors which were named as Self-awareness \& Balanced Processing and Transparency \& Authenticity. The resulting factors in this study were also named as Self-awareness \& Balanced Processing and Transparency \& Authenticity which is compatible with 
Gündoğdu's study. However, two items of Transparency \& Authenticity dimension were listed under the Self-awareness \& Balanced Processing dimension.

The Reliability Analysis was repeated for two factors of authentic leadership measure after the factor analysis. Both of the factors are highly reliable. The cronbach's alpha values are .94 for Self-awareness \& Balanced Processing and .90 for Transparency \& Authenticity respectively which is above the generally accepted score .70 .

Table 3: Factor Analysis Results of Authentic Leadership Scale

Factor 1: Self-awareness \& Balanced Processing \% variance: 40.577

Factor Loadings

2. Knows when it is time to reevaluate his or her positions on important issues $\quad .822$

11. Listens carefully to different points of view before coming to conclusions $\quad .798$

$\begin{array}{ll}\text { 6. Encourages everyone to speak their minds } & .788\end{array}$

3. Shows he or she understands how specific actions impact others .785

10. Analyzes relevant data before coming to a decision $\quad .730$

4. Instills pride in me for being associated with him/her $\quad .702$

1. Accurately describes how others view his or her capabilities .694

12. Solicits views that challenge his or her deeply held positions .693

5. Admits mistakes when they are made $\quad .630$

Factor 2: Transparency \& Authenticity

\% variance: 28.384

14. Makes decisions based on his or her core values $\quad .842$

15. Asks you to take positions that support your core values $\quad .819$

16. Makes difficult decisions based on high standards of ethical conduct $\quad .784$

8. Displays emotions exactly in line with feelings $\quad .674$

9. Tells you the hard truth $\quad .673$

Kaiser-Meyer-Olkin Measure of Sampling Adequacy: .946

$\begin{array}{lll}\text { Bartlett's Test of Sphericity: } .000 & \text { Chi-Square : } 2629.911 \quad \text { df: } .120\end{array}$

50 items of organizational learning measure were entered into factor analysis. Kaiser-Meyer-Olkin (KMO) value was found as .929 and this value is mostly above the generally accepted adequacy level of .60. This result demonstrated the homogeneous structure of the items and the result of Bartlett Test (.000, Chi-Square: 7013.984, df: .1225) showed that the items were convenient for factor analysis.

Items 8 and 10 from individual-level section, items 8 and 9 from organization-level section, items 4,5 and 8 from feedforward section, items 1,2,3,4,5,6 and 10 from feed-back section were left out of the analysis due to cross loadings. The remaining 36 items were loaded on five factors explaining $61.927 \%$ of the total variance.

The Reliability Analysis was repeated for five factors of Organizational Learning scale after factor analysis. All of the factors are highly reliable. The cronbach's alpha values are .91 for Individual-level Learning, .90 for Group-level Learning, .92 for Organization-level Learning, .88 for Feed-forward Learning and .75 for Feed-back Learning respectively which is above generally accepted score .70 .

Table 4: Factor Analysis Results of Organizational Learning Scale

2. Individuals are aware of the critical issues that affect their work. 768

1. Individuals are current and knowledgeable about their work. 
5. Individuals feel confident in their work.

3. Individuals feel a sense of accomplishment in what they do. $\quad .640$

6. Individuals feel a sense of pride in their work. $\quad .628$

4. Individuals generate many new insights. $\quad .587$

7. Individuals have a high level of energy at work.

9. Individuals have a clear sense of direction in their work.

Factor 2: Group-level Learning \% variance: 14.006

2. We share our successes within the group. $\quad .727$

4. Ideas arise in meetings that did not occur to any one individual. $\quad .719$

3. We share our failures within the group. $\quad 661$

10. Groups are prepared to rethink decision when presented with new information. $\quad .658$

9. Different points of view are encouraged in group work. $\quad .646$

6. Groups in the organization are adaptable.

5. We have effective conflict resolution when working in groups.

1. In meetings, we seek to understand everyone's point of view.

7. Groups have a common understanding of departmental issues. $\quad .522$

8. Groups have the right people involved in addressing the issues. $\quad .507$

Factor 3: Organization-level Learning \% variance: 13.957

6. We have a realistic yet challenging vision for the organization. .805

5. The organization's culture could be characterized as innovative. $\quad .759$

2. The organizational structure supports our strategic direction. $\quad .755$

1. We have a strategy that positions us well for the future.

7. We have the necessary systems to implement our strategy. $\quad .695$

3. The organizational structure allows us to work effectively. 648

4. Our operational procedures allow us to work efficiently. $\quad .590$

10. We have an organizational culture characterized by a high degree of trust. $\quad .584$

Factor 4: Feed-forward Learning \% variance: 12.595

9. The "left hand" of the organization knows what the "right hand" is doing. $\quad .672$

6. Individuals compile information for everyone to use. $\quad .659$

$\begin{array}{ll}\text { 10. Results of the group are used to improve products, services and processes. } & .639\end{array}$

1. Lessons learned by one group are actively shared with others. $\quad 634$

3. Groups propose innovative solutions to organizationwide issues. $\quad .625$

2. Individuals have input into the organization's strategy. $\quad .602$

7. Individuals challenge the assumptions of the group. .562

\section{Factor 5: Feed-back Learning ～\% variance: 6.237}

8. Training is readily available when it is needed to improve knowledge and skills. $\quad .694$

7. Information systems make it easy for individuals to share information. 667

9. Cross-training, job rotation and special assignments are used to develop

a more flexible workforce.

.630 
Kaiser-Meyer-Olkin Measure of Sampling Adequacy: .931

Bartlett's Test of Sphericity: $.000 \quad$ Chi-Square : $4773.178 \quad 630$

\subsection{Correlation Analysis}

Correlations related to independent variable and all factors of dependent variable were detailed in Table 5. In general, all significant correlations are ranging from .256(p<.01) to $.763(p<.01)$. Hypothesis 1 was tested using correlation analysis. Table 5 represents the results of the correlation analysis. Authentic leadership is significantly $(p<.01)$ correlated with organizational learning. Hypothesis 1 stating that "there is a relationship between authentic leadership and organizational learning" is supported.

Table 5: Correlations Between Authentic Leadership and Organizational Learning

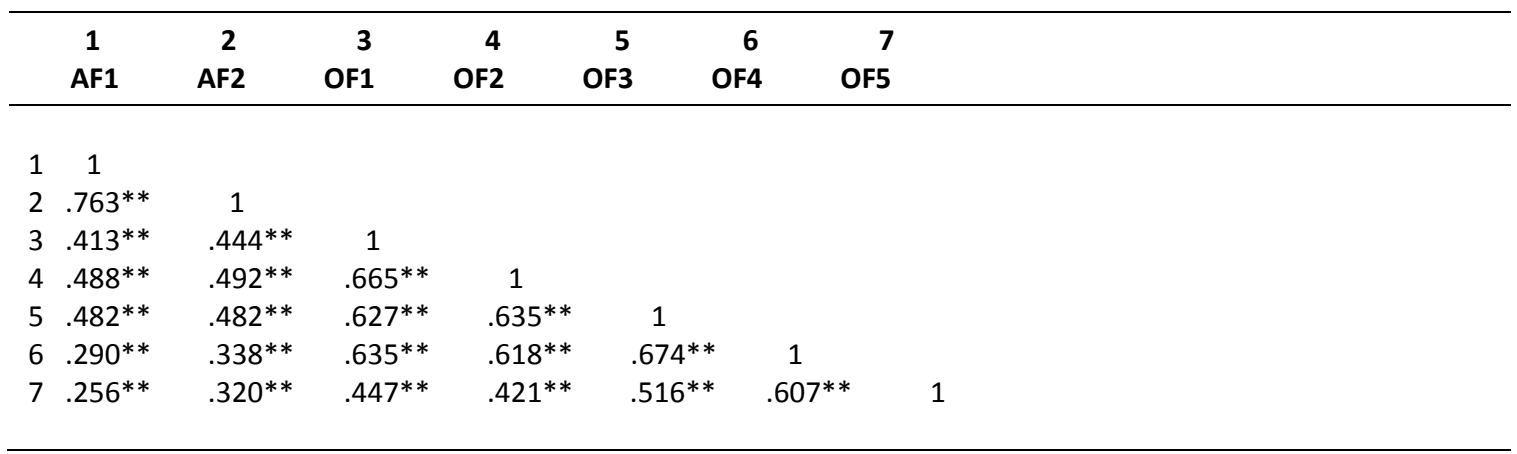

** Correlation is significant at the 0.01 level (2-tailed).

Variables are represented by the following symbols:

Authentic Leadership Factors; AF1: Self-awareness \& Balanced Processing, AF2: Transparency \&Authenticity

Organizational Learning Factors; OF1: Individual-level Learning, OF2: Group-level Learning,

OF3: Organization-level Learning , OF4: Feed-forward Learning , OF5: Feed-back Learning

\subsection{Regression Analysis}

Multiple regression analysis was used in order to analyze the contribution of authentic leadership on organizational learning. Results showed that self-awareness \& balanced processing does not contribute to individual-learning. On the other hand, transparency \&authenticity has positively and moderately $(\beta=.309 ; p$ value $=.002)$ contributes to individual-level learning dimension. Results are tabulated in Table 6.

Table 6: Results of the Multiple Regression Analysis for Testing the Main Effect of Authentic Leadership Factors on Individual-level Learning

Dependent Variable: Individual-level Learning

$\begin{array}{llll}\text { Independent Variables: } & \boldsymbol{\beta} & \text { t value } & \text { p value } \\ & & & \\ \text { Self-awareness \& Balanced Processing } & .177 & 1.805 & .073 \\ \text { Transparency \& Authenticity } & .309 & 3.158 & .002\end{array}$

$\mathbf{R}=.459 ; \mathbf{R}^{2}=.210 ; \quad \mathbf{F}$ value $=26.224 ; \quad \mathbf{p}$ value $=.000$

Results of the multiple regression analysis between authentic leadership factors and the group level learning factor of organizational learning showed that both Self-awareness \& Balanced Processing and Transparency \& Authenticity positively and moderately $(\beta=.270, .286 ; p$ value $=.005, .003)$ contributes to group-level learning dimension. Results are shown in Table 7. 
Table 7: Results of the Multiple Regression Analysis for Testing the Main Effect of Authentic Leadership Factors on Group-level Learning

Dependent Variable: Group-level Learning

$\begin{array}{lccc}\text { Independent Variables: } & \boldsymbol{\beta} & \text { t value } & \text { p value } \\ & & & \\ \text { Self-awareness \& Balanced Processing } & .270 & 2.867 & .005 \\ \text { Transparency \& Authenticity } & .286 & 3.042 & .003\end{array}$

$\mathbf{R}=.522 ; \quad \mathbf{R}^{2}=.272 ; \quad \mathbf{F}$ value $=36.815 ; \quad \mathbf{p}$ value $=.000$

Similarly Group-level Learning, both Self-awareness \& Balanced Processing and Transparency \& Authenticity positively and moderately $(\beta=.273 ; p$ value $=.004)$ contributes to organization-level learning dimension. Results are tabulated in Table 8 .

Table 8. Results of the Multiple Regression Analysis for Testing the Main Effect of Authentic Leadership Factors on Organization-level Learning

Dependent Variable: Organization-level Learning

$\begin{array}{lccc}\text { Independent Variables: } & \boldsymbol{\beta} & \text { t value } & \text { p value } \\ & & & \\ \text { Self-awareness \& Balanced Processing } & .273 & 2.892 & .004 \\ \text { Transparency \& Authenticity } & .273 & 2.888 & .004\end{array}$

$\mathbf{R}=.513 ; \mathbf{R}^{2}=.263 ; \quad \mathbf{F}$ value $=35.215 ; \quad \mathbf{p}$ value $=.000$

Self-awareness \& Balanced Processing does not contribute to feed-forward learning dimension of organizational learning, on the other hand, Transparency \& Authenticity positively and moderately $(\beta=.278 ; p$ value $=.008)$ contributes to feedforward learning dimension as tabulated in Table 9.

Table 9: Results of the Multiple Regression Analysis for Testing the Main Effect of Authentic Leadership Factors on Feedforward Learning

$\begin{array}{lccc}\text { Dependent Variable: Feed-forward Learning } & & \\ & & & \\ \text { Independent Variables: } & \boldsymbol{\beta} & \mathbf{t} \text { value } & \mathbf{p} \text { value } \\ & & & \\ \text { Self-awareness \& Balanced Processing } & .078 & .753 & .452 \\ \text { Transparency \& Authenticity } & .278 & 2.685 & .008 \\ & & & \\ \mathbf{R}=.341 ; \quad \mathbf{R}^{\mathbf{2}}=.116 ; \quad \mathbf{F} \text { value= } & & \end{array}$

Similarly, Self-awareness \& Balanced Processing factor of authentic leadership does not significantly contribute to feedback learning, on the other hand, Transparency \& Authenticity positively and moderately $(\beta=.298 ; p$ value $=.000)$ contribute to feed-back learning dimension as seen in Table 10. 
Table 10: Results of the Multiple Regression Analysis for Testing the Main Effect of Authentic Leadership Factors on Feedback Learning

Dependent Variable: Feed-back Learning

$\begin{array}{lccc}\text { Independent Variables: } & \boldsymbol{\beta} & \text { t value } & \text { p value } \\ & & & \\ \text { Self-awareness \& Balanced Processing } & .029 & .278 & .781 \\ \text { Transparency \& Authenticity } & .298 & 2.857 & .005\end{array}$

$\mathbf{R}=.321 ; \quad \mathbf{R}^{2}=.103 ; \quad \mathbf{F}$ value $=11.301 ; \quad \mathbf{p}$ value $=.000$

\section{CONCLUSION}

Learning with the most general definition; refers to a permanent change in experience resulting in behavior. Learning as a cognitive and physical activity, enable obtain new knowledge and skills and shapes behavior through the acquired knowledge and skills (Schwandt \& Marquardt, 2000). Learning is not a phenomenon that starts and ends at an instant, it is a dynamic process consisting of phases and continuing for life (Crossan, Lane, \& White, 1999). Enterprises in the new economic environment; to adapt to change, to overcome uncertainty, to provide competitive advantage and to influence the environment should pay attention to learning. Learning provides systematic problem solving and recovery for organizations. Learning-oriented organizations differ from their competitors by developing methods to make unlimited use of knowledge. These organizations are the one that share their visions with their employees, view learning as an investment element, attach importance to creating, sharing and using information, questioning organizational norms, modifying and, when necessary, changing organizational performance, quality and customer satisfaction (Burnes, 2009). According to Burnes (2009) in order to survive or expand the business, organizational learning must be encouraged by leaders. At this point, leader's positive behaviors generate positive ascension on organizational learning. Authentic leadership style which is the independent variable of this study focuses on positive thoughts such as hope, stamina, patience, optimism, welfare and the applicability of these conducts to the business life (Avolio, O.Walumbwa, \& J.Weber, 2009). In that respect, the positive influence of authentic leadership style on organizational learning stand for the basis of this study.

As mentioned in the theoretical framework of this study, the independent variable of the study which is authentic leadership has four dimensions in the literature; these are (1) self-awareness, (2) balanced processing, (3) relational transparency, and (4) ethical/moral conduct. However, authentic leadership yielded two factors in this study which were named as self-awareness \& balanced processing and transparency \& authenticity. This outcome is compatible with Gündoğdu (2010)'s study. Self-awareness \& balanced processing factor refers to the values, identity, emotions, motives and goals of an individual as well as, interpreting all the related data objectively during decision making process free from bias. Transparency \& authenticity factor represents that the leader has unconditional trust and self-closure in his/her relationships and act in an ethical way in any case.

As a result of the factor analysis applied to the research data, it has been seen that the learning orientation is composed of five factors. These factors, in accordance with the views in the relevant literature, include three learning stocks (individuallevel, group-level, and organization-level), and two learning flows (feed-forward and feed-back). Learning stocks refer to absorbing knowledge in different levels in the organization and while learning flows states for movement of knowledge from one level to another. Results of the factor analysis show that factor structures of both terms show similarity with the factor structure of the previous studies ((Bontis, Crossan, \& Hulland, 2002; Crossan M. a., 1997; Vera, 2004).

In addition, results of correlation analysis showed that there is a significant and positive correlation between authentic leadership and organizational learning factors, namely three learning stocks: individual, group, organization and two learning flow: feed-forward and feed-back. Although, in literature there is no study showing the relationship between organizational learning and authentic leadership style, previous research represent that organizational learning is associated with different kinds of leadership styles. For instance, Noruzy, Dalfard, Azhdari, Nazari-Shirkouhi and Rezazadeh (2013) have conducted a study which revealed a strong correlation between transformational leadership and organizational learning. Similarly, Lakhani (2005) has found that visionary leadership is highly correlated with organizational learning.

Moreover, regression analysis was conducted to determine the effect of authentic leadership on organizational learning within the framework of reaching the main goal of the research. According to the results of regression analysis; leader's 
self-awareness and balanced processing behavior do not contribute to individual-level learning. On the other hand, it positively and moderately contributes to group-level and organization-level learning. This means that increase in the leader's values, identity, emotions, motives and goals also increases learning stocks in the organization except individuals. In addition, higher decision making free from bias increases improvement of collective mind and shared understanding in the organization. In other words, higher self-aware leaders increase interactions between people, procedures, structures, systems and strategy in the organization. The previous research conducted by Aragon-Correa and his colleagues (2007) revealed similar findings concerning the leadership style promotes creating collective mind in the organization that leads to organizational learning development.

Another finding of regression analysis was concerning the learning flows; self-awareness \& balanced processing does not contribute to feed-forward and feed-back learning. This means that if the leader has ability to assess any kind of situation objectively, then there is not a direct bearing on organizational members to retain and reuse of knowledge. In other words, higher or lower self-awareness and objectiveness of a leader has no effect on absorbing new learning and usage of past learning. On the other hand, transparency \& authenticity factor of authentic leadership positively and moderately contributes to organizational learning. This means that increase in sharing information unconditionally also increases collecting, managing and using knowledge in the organization. In other words, higher trustworthy environment increases free exchange of knowledge in the organization. These findings were also supported by the literature. Several previous studies show that corresponding trust between followers and leaders generates affirmative upward spirals on collective processes of organizational learning (Lakhani, 2005; Zagoršek, Dimovski, \& Škerlavaj, 2009; Glessner, 2016).

\subsection{Limitations}

The sample size was one of the limitations of this study. The target population is consisted of four organizations from banking and insurance sector with limited number of leaders. Sector and organization limitations have virtually eliminated the chance of making comparisons between different sectors, organizations and leaders. Besides, participation to the study was voluntary and sample consisted of some part of the staff especially knowledge workers (developers, analysts, specialists and consultants) who are volunteer to answer the questionnaire. These restrictions among target population made it difficult to generalize the findings.

Another limitation about the study is about the time horizon of the study. The study is cross-sectional and the data were collected at a single point in time. Longitudinal studies may provide more fruitful results.

Finally, there are numerous uncontrolled confounding variables in this study such as global economic issues, technological changes, national culture effects, employee satisfaction, etc. These circumstances may have delimited the relationship between authentic leadership and organizational learning factors.

\subsection{Managerial Implications and Suggestions for Future Research}

Understanding how organizational learning is crucial for organizations to catch-up competitiveness in this ever changing business environment. If the organizations want to remain competitive they must invest in increasing the competencies and capabilities of learning stocks and improving learning flow channels.

The results of this study revealed that authentic leadership style has a significantly positive effect on organizational learning. Under these findings; leaders should be informed about the details about authentic leadership style. Moreover, training programs about this topic among leaders should be arranged by human resources departments.

Given the consequences of authentic leadership and organizational learning, and the importance of both of them in terms of their business, organizations need to look for ways to increase their learning orientation with strategies and the authenticity of their leaders in order to extend their lives and provide sustainable competitive advantage. In today's hypercompetitive environment, businesses can differentiate from their competitors and sustain their presence by developing new products, processes and ideas. Innovation is a phenomenon based on the creation, sharing and use of information about the market, products, processes and technology, or learning in other words. In addition, learning versatility enables information to be gathered from the organization, to connect the information to each other, and to allow the opportunity to see changes and occurrences around it. Business executives must get rid of the narrow view of learning as a cost and must put the concept of learning at the center of development, growth and living.

Despite the limitations of this study, the significance of two interrelated variables; organizational learning and authentic leadership, shed light on managers by providing clues about their benefits in terms of organization's success. Using the results reached in this study; organizations may get benefit while developing strategy, policy and particularly human resources applications. It is one of the most important contributions of this study that helps leaders direct their actions to facilitate learning in organizations. The findings of this research study help leaders determine specific approaches to 
encourage learning because organizational learning is becoming a critical issue for organization after competition has intensified. Leadership depends on the complexity of the global business environment, the continuity of the organization, and the ability of authentic leaders to make the organization learn more quickly. The results of this research are helping leaders to have in-depth knowledge of the complex roles of them and seeking guidance with authentic leadership in the organizational learning process.

This quantitative research do not cover cultural implications as survey was applied in one country; Turkey. As the nature of the organizational learning, there might be differences among different national cultures in context of learning flows. For instance, in Anglo-Saxon culture, open communication is encouraged rather than French partners. Similarly, Japanese workers need frequent dialogue with their associates because of their analytical skills weakness. It is obvious that, incremental interaction in cultural characteristics promotes organizational learning environment. In terms of leadership style; Japanese leaders communicate openly with their co-workers as a reason of uncertainty avoidance which leads knowledge creation in the organization. This characteristic diversifies Japanese from other national cultures. (Bontis N. C., 2002). For future research, national culture effect on the relationship between authentic leadership and organizational learning may be investigated. In addition to culture, enlarging model with different moderating or mediating variables such as climate, organization's structure or trust may be important in terms of adding richness and depth to the subject. On the other hand, other than authentic leadership style, relationship between various different leadership styles and organizational learning could be subject to future studies.

In this study, all data were collected with the help of a questionnaire, using quantitative research methodology and this technique is limited in the meaning of sample and scale. It may be useful to conduct research using different measurement methods, such as interviews on a more diverse sample in subsequent studies. Future research may model the organizational learning and authentic leadership using a group that also involves non-knowledge workers along knowledgeworkers. Another suggestion about the methodology for future studies might be using mixed methods; particularly, interviews with the key people in the organization or focus group techniques to triangulate the survey responses that are insufficient to address complicated issues in leadership and organizational learning.

\section{REFERENCES}

Arago'n-Correa. J. A.. García-Morales. V. J.. \& Cordo'n-Pozo. E. (2007). Leadership and organizational learning's role on innovation and performance: Lessons from Spain. Industrial Marketing Management. vol. 36 pp. 349 - 359.

Argyris. C.. \& Schön. D. A. (1996). Organizational Learning II Theory. Method and Practice. United States: Addison-Wesley Publishing Company. Inc.

Ataman. G. (2002). Iş̧letme Yönetimi Temel Kavramlar ve Yeni Yaklaşımlar . İstanbul: Türkmen Kitabevi.

Avolio. B. J.. \& Gardner. W. L. (2005). Authentic leadership development: Getting to the root of positive forms of leadership. The Leadership Quarterly. Vol 16 pp.315-338.

Avolio. B. J.. \& Gardner. W. L. (2005). Authentic Leadership Development: Getting to the Root of Positive Forms of Leadership. The Leadership Quarterly. 16. 315-338.

Avolio. B. J.. Luthans. F.. \& Walumbwa. F. O. (2004). Authentic Leadership: Theory Building for Veritable Sustained Performance. Working Paper. Gallup Leadership Institute: University of Nebraska-Lincoln.

Avolio. B. J.. O.Walumbwa. F.. \& J.Weber. T. (2009). Leadership: Current Theories. Research. and Future Directions. Annual Review of Psychology. 60:421-449.

Avolio. B. J.. Walumbwa. F.. \& Weber. T. J. (2009). Leadership: Current Theories. Research and Future Directions. The Annual Review of Psychology. 421-449.

Aydogdu. S.. \& Asikgil. B. (2011). The Effect of Transformational Leadership Behavior on Organizational Culture: An Application in Pharmaceutical Industry. International Review of Management and Marketing. Vol. 1. No. 4. pp.65-73.

Baltaş. A. (2000). Değişimin içinden geleceğe doğru ekip çalışması ve liderlik. İstanbul: Remzi Kitabevi.

Bass. B. M. (2003). Ethics. Moral Character and Authentic Transformational Leadership. Leadership Quarterly. 10(2). 1-22.

Bass. B. M. (2008). The Bass Handbook of Leadership: Theory. Research. and Managerial Applications. New York: The Free Press.

Bender. P. U. (1998). Leadership from Within. Canada: Stoddart.

Bennis. W. (2009). On Becoming a Leader. New York: Basic Books. 
Berson. Y.. Da'as. R.. \& Waldman. D. A. (2015). How Do Leaders and Their Teams Bring About Organizational Learning and Outcomes? Personnel Psychology. Vol. 68. pp.79-108.

Bloch. S.. \& Whiteley. P. (2003). Complete Leadership. London: Momentum.

Bontis. N. (1999). Managing an organizational learning system by aligning stocks and flows of knowledge: An empirical examination of intellectual capital. knowledge management. and business performance. Doctoral Dissertation. The University of Western Ontario (Canada).

Bontis. N. C. (2002). Managing an organizational learning system by aligning stocks and flows. Journal of Management Studies 39(4). 437469.

Bontis. N.. Crossan. M. M.. \& Hulland. J. (2002). Managing an organizational learning system by aligning stocks and flows. Journal of Management Studies 39(4). 437-469.

Burnes. B. (2009). Managing Change. London: Pearson Education.

Chilton. M. A.. \& Bloodgood. J. M. (2014). Knowledge Management and Competitive Advantage: Issues and Potential Solutions . United States: IGI Global.

Crossan. M. a. (1997). Measuring organizational learning. Boston. MA: Ivey Working Paper.

Crossan. M. M.. Lane. H. W.. \& White. R. E. (1999). An Organizational Learning Framework: From Intuition to Institution. Academy of Management Review. Vol.24. No.3. 522-537.

Çakmakyapan. S. (2009). Dönüşümsel ve Etkileşimsel Liderlik Davranışlarının Örgütsel Öğrenme Üzerindeki Etkilerini Belirlemeye Yönelik Bir Araştırma. Master Thesis. İstanbul: İstanbul Üniversitesi.

Çam. S. (2002). Öğrenen Organizasyon ve Rekabet Üstünlüğü. İstanbul: Papatya.

Daft. R. L.. \& Weick. K. E. (1984). Toward a model of organizations as Interpretation systems. The Academy of Management Review. 284.

Dictionaries. O. (2012). Paperback Oxford English Dictionary. Oxford: Oxford Dictionaries.

Egan. T. M. (2004). The effects of organizational learning culture and job satisfaction on motivation to transfer of learning and turnover intention. Human Resource Development Quarterly. 15(3).

Eren. E. (2004). Örgütsel Davranıs ve Yönetim Psikolojisi. İstanbul: Beta Basım Yayım Dagıtım A.S.

Erickson. R. J. (1995). The Importance of Authenticity for Self and Society. Symbolic Interaction 18(2). 121-144.

Ertürk. M. (1999). İşletmelerde Yönetim Ve Organizasyon. İstanbul: Beta Basım Yayın Dağıtım AŞ.

Fairholm. G. W. (1991). Values Leadership: Toward a New Philosophy of Leadership. New York: Praeger.

Gardner. W. L. (2005). Can You See the Real Me? A Self-Based Model of Authentic Leader and Follower Development. The Leadership Quarterly.16(3). 343-372.

Gardner. W. L.. Avolio. B. J.. Luthans. F.. May. D. R.. \& Walumbwa. F. (2005). "Can you see the real me?" A self-based model of authentic leader and follower development. The Leadership Quarterly. Vol 16 pp.343-372.

Gardner. W. L.. Cogliser. C. C.. Davis. K. M.. \& Dickens. M. P. (2011). Authentic leadership: A review of the literature and research agenda. The Leadership Quarterly. Vol 22. pp.1120-1145.

Glessner. T. (2016). Correlation between Servant Leadership and Organizational Learning in a Military Socio-cultural Archetype: Innovation of Strategic and Operational Capabilities. Dissertion. Arizona: Northcentral University.

Harter. S. (2002). Authenticity. In C.R.Snyder. \& S.Lopez. Handbook of Positive Psychology (pp. 382-394). UK: Oxford University Press.

Jensen. S.. \& Luthans. F. (2006). Entrepreneurs as Authentic Leaders: Impact on Employee Attitudes. Leadership and Organization Development Journal. Vol. 27. No. 8. 646-666.

Johnson. C.. \& Schwandt. D. (1998). Organizational Action Survey. Ashburn: Center for the Study of Learning. George Washington University.

Jones. G. (2010). Organizational Theory. Design and Change. New Jersey: Pearson Prentice Hall.

Kernis. M. (2003). Towards a conceptualization of Optimal Self-Esteem. Psychological Inquiry 14(1). 1-26.

Kidd. T. T. (2009). Handbook of Research on Technology Project Management. Planning and Operations. New York: IGI Global.

Kirkpatrick. S. A.. \& Locke. E. A. (1991). Leadership: do traits matter? Academy of Management Executive. Vol. 5 No. 2 pp. $48-60$.

Klenke. K. (2007). Authentic Leadership: A Self. Leader. and Spiritual Identity Perspective. International Journal of Leadership Studies. Vol. 3 Iss. 1. 2007. pp. 68-97. 
Koçel. T. (2005). İşletme Yöneticiliği. İstanbul: Arıkan Basın Yayım Dagıtım Ltd. Sti.

Lakhani. M. A. (2005). Relational linkages between visionary leadership and organizational learning across the United States. Malaysia. and India. Dissertion. University of Phoenix.

Liu. L. (2010). Conversations on Leadership. San Francisco: Jossey-Bass A Wiley Imprint.

Luthans. F. (2002a). The Need for and Meaning of Positive Organizational Behavior. Journal of Organizational Behavior Vol. 23. Iss. 6. 695.

Luthans. F. (2002b). Positive Organizational Behavior: Developing and Managing Psychological Strengths. Academy of Management Executive Vol.16. 57-72.

Luthans. F. a. (2003). Authentic leadership: A positive developmental approach. In Cameron. K.S. and Dutton. J.E. and Quinn. R.E. (Eds.). Positive organizational scholarship. 241-261.

Maurik. J. v. (2001). Writers on Leadership. London: Penguin Business.

May. D. R.. Hodges. T. D.. Chan. A. Y.. \& Avolio. B. J. (2003). Developing the Moral Component of Authentic Leadership. Organizational Dynamics. Vol. 32. No. 3. pp. 247-260.

Mescon. M. H.. Albert. M.. \& Khedouri. F. (1988). Management. Philadelphia: Harpercollins College Div. 3 Sub Edition.

Michael. M. E.. \& Slocum. J. W. (1993). Unlearning the Organization. Organizational Dynamics. Vol: 22.

Moorhead. G.. \& Griffin. R. W. (1998). Organizational Behavior. Boston: Houghton Mifflin Company.

Moses. J. J.. \& Liang. T. (1990). Leadership. leadership development. and the national centre for research in. Berkeley. CA: National Centre for Research in Vocational Education.

Nahavandi. A.. \& Malekzadeh. A. R. (1999). Organizational Behavior The Person-Organization Fit. New Jersey: Prentice-Hall. Inc.

Naktiyok. S. (2012). Örgütsel Öğrenme ve Örgütsel Bağlılık ilişskisi. Erzurum: Atatürk Üniversitesi.

Northouse. P. G. (2015). Leadership: Theory and Practice. CA: SAGE Publications. Inc.

Noruzy. A.. Dalfard. V. M.. Azhdari. B.. Nazari-Shirkouhi. S.. \& Rezazadeh. A. (2013). Relations between transformational leadership. organizational learning. knowledge management. organizational innovation. and organizational performance: an empirical investigation of manufacturing firms. International Journal of Advanced Manufacturing Technology. 64:1073-1085.

Rose. R. C. (2009)). The Effect Of Organizational Learning On Organizational Commitment. Job Satisfaction And Work Performance. Universiti Putra Malaysia.

Rost. J. C. (1991). Leadership For The Twenty-First Century. Westport: Greenwood Publishing Group. Inc.

Saklofske. D.. \& Zeidner. M. (1995). International Handbook of Personality and Intelligence. New York: Plenum Press.

Sashkin. M.. \& Rosenbach. W. (1996). The Leadership Profile. Seabrook: Ducochon Press.

Schwandt. D. R.. \& Marquardt. M. J. (2000). Organizational Learning From World-Class Theories to Global Best Practices. Florida: CRC Press LLC.

Seligman. M. E. (1990). Learned Optimism. Sydney: Random House.

Senge. P.. Ross. R.. Smith. B.. Roberts. C.. \& Kleiner. A. (1994). The Fifth Discipline Fieldbook:Strategies and Tools for Building a Learning Organization. New York: Crown Business.

Snyder. N. (1999). Vision. Values and Courage Leadership For Quality Management. USA: The Tree Press.

Spears. L. C.. \& Lawrence. M. (2002). Focus on Leadership: Servant-Leadership for the Twenty-First Century. New York: John Wiley \& Sons. Inc.

Spillane. J. P. (2006). Distributed Leadership. San Francisco: Jossey-Bass A Wiley Imprint.

Vera. D. \&. (2004). Strategic leadership and organizational learning. The Academy of Management Review. 29(2). 222-240.

Yazıcı. S. (2001). Öğrenen Organizasyonlar. Bursa: Alfa Yayınları.

Yılmaz. A.. \& Akdemir. S. (2005). Örgütlerde Vizyon ve Yönetimi. Ankara: Detay Yayıncllık.

Yukl. G. (2006). Leadership in Organizations. New Jersey: Pearson Prentice Hall.

Zagoršek. H.. Dimovski. V.. \& Škerlavaj. M. (2009). Transactional and transformational leadership impacts on organizational learning. Journal for East European Management Studies. vol 2. 